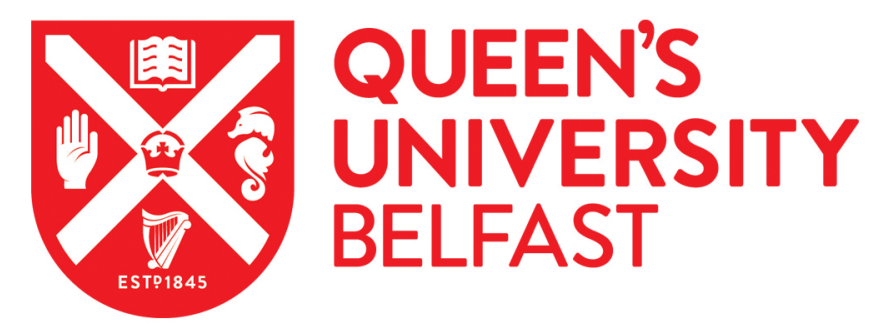

\title{
Exploring the impact of megaproject environmental responsibility on organizational citizenship behaviors for the environment: A social identity perspective
}

Wang, G., He, Q., Meng, X., Locatelli, G., Yu, T., \& Yan, X. (2017). Exploring the impact of megaproject environmental responsibility on organizational citizenship behaviors for the environment: A social identity perspective. International Journal of Project Management, 35(7), 1402-1414.

https://doi.org/10.1016/j.ijproman.2017.04.008

\section{Published in:}

International Journal of Project Management

\section{Document Version:}

Peer reviewed version

Queen's University Belfast - Research Portal:

Link to publication record in Queen's University Belfast Research Portal

\author{
Publisher rights \\ Copyright 2017 Elsevier. \\ This manuscript is distributed under a Creative Commons Attribution-NonCommercial-NoDerivs License \\ (https://creativecommons.org/licenses/by-nc-nd/4.0/), which permits distribution and reproduction for non-commercial purposes, provided the \\ author and source are cited.
}

\section{General rights}

Copyright for the publications made accessible via the Queen's University Belfast Research Portal is retained by the author(s) and / or other copyright owners and it is a condition of accessing these publications that users recognise and abide by the legal requirements associated with these rights.

Take down policy

The Research Portal is Queen's institutional repository that provides access to Queen's research output. Every effort has been made to ensure that content in the Research Portal does not infringe any person's rights, or applicable UK laws. If you discover content in the Research Portal that you believe breaches copyright or violates any law, please contact openaccess@qub.ac.uk. 


\title{
Exploring the impact of megaproject environmental responsibility on organizational citizenship behaviors for the environment: A social identity perspective
}

\begin{abstract}
The importance of organizational citizenship behaviors for the environment (OCBEs) has been clearly established in the environmental literature. However, the OCBEs construct has rarely been examined in the specific and increasingly important realm of megaproject environmental responsibility (MER). To fill this gap, this paper presents an individual-level analysis that explores the impact of project participants' perceptions of MER practices on their environmental commitment and OCBEs. The results show that project participants' perceptions of MER practices directed toward internal stakeholders (i.e., stakeholders linked by project contracts) are positively related to their OCBEs. This relationship is partially mediated by the environmental commitment of project participants. Conversely, project participants' perceptions of MER practices directed toward external stakeholders (i.e., the local community and general public) have only an insignificant impact on their OCBEs. These findings provide new insights for managing MER practices to stimulate the emergence of OCBEs and thereby improve environmental performance.
\end{abstract}

Keywords: Megaproject; Environmental responsibility; Organizational citizenship behaviors for the environment; Environmental commitment; Social identity theory 


\section{1. Introduction}

2 Megaprojects are temporary endeavors with a large investment commitment, vast

3 complexities (especially in organizational terms), and long-lasting impacts on the economy,

4 environment, and society (Brookes and Locatelli, 2015). In the engineering sector,

5 megaprojects refer to large-scale infrastructure projects that are usually financed by

6 governments and are characterized by "enormous resource consumptions, significant

7 environmental impacts, as well as a high level of risk, innovation, and complexity" (Flyvbjerg,

8 2014; Locatelli and Mancini, 2010; Locatelli et al., 2017a; Van Marrewijk et al., 2008).

9 In the global context of sustainable development, improving environmental performance is one of the most pressing and prominent objectives in megaproject management (Locatelli and Mancini, 2013; Zeng et al., 2015). As megaprojects increase their efforts in environmental management, the key challenge is to translate formal project policies into innovative and spontaneous individual initiatives (Locatelli et al., 2017b; Maier and Branzei, 2014). Where individual involvement is insufficient, the application of environmental management policies and systems tends to be disconnected from daily activities and to be implemented symbolically rather than substantively (Boiral et al., 2016).

\subsection{OCBEs in megaproject}

Boiral (2009) defined organizational citizenship behaviors for the environment (OCBEs) as comprising "individual, voluntary, and discretionary social behaviors that are not explicitly recognized by the formal management system and that contribute to effective environmental management by organizations." Examples of OCBEs include helping to resolve environmental issues, suggesting solutions aimed at preventing pollution, and collaborating 
with environmental departments to implement green technologies.

The megaproject is an exemplary case of a complex, dynamic, and temporary organization. Compared to "regular projects," megaprojects have more ambiguous roles and boundaries, and more informal coordination activities between teams (Hanisch and Wald, 2014; Sainati et al., 2017; Van Marrewijk et al., 2008). As a form of innovative and spontaneous initiative that goes beyond the prescribed role requirements (Ekrot et al., 2016), OCBEs are essential to compensate for the limitations of formal management systems in megaprojects (He et al., 2015) and have far-reaching impacts on project success (Braun et al., 2013; Turner and Zolin, 2012).

The Shanghai World Expo project attached high importance to environmental protection and took a variety of environmentally conscious initiatives (Zhang, 2013). For example, it launched a "golden idea" activity to seek constructive suggestions from project participants and the application of these suggestions played an important role in reducing energy consumption and enhancing environmental protection (He et al., 2015). Astonishingly, although OCBEs have been extensively valued by megaproject management (as in the Shanghai World Expo), this research area remains underdeveloped. Furthermore, the social-psychological mechanisms that lead project participants to engage in OCBEs are as yet largely unexplored.

\subsection{Research purpose and question}

This paper contributes to megaproject management research by proposing and validating a predictive model for OCBEs. The findings in this paper can serve as a guide for megaproject managers to promote OCBEs and thereby facilitate the improvement of project environmental 
performance. According to the burgeoning OCBEs literature, "if individuals are aware that becoming sustainable is an important objective of their organization and the organization demonstrates an interest in supporting environmental responsibility practices, they may be more prone to reciprocate by performing OCBEs" (Paillé and Raineri, 2015; Raineri and Paillé, 2016). Nevertheless, why, how, and under what circumstances organizational environmental responsibility practices lead to individual OCBEs remains largely unknown (Paillé et al., 2014; De Roeck and Delobbe, 2012). Environmental commitment refers to a sense of attachment to and identification with the environmental goals and values of an organization, and it serves as a bridge between the organization's environmental responsibility practices and individual OCBEs (Raineri and Paillé, 2016). Therefore, this study empirically investigates the relationships between project participants' perceptions of megaproject environmental responsibility (MER) practices and their OCBEs, considering the mediating effect of their environmental commitment.

To date, scholars have explored the contextual antecedents of individual-level OCBEs in terms of organizational-level practices, including environmental management practices (Paillé et al., 2013), organization environmental policies (Raineri and Paillé, 2016; Paillé and Raineri, 2015), and human resource management (Paillé et al., 2014). The authors leveraged this body of knowledge, along with primary data, to provide guidelines for managing OCBEs in megaprojects. To analyze how project-level factors influence individual-level OCBEs, this study developed an empirical model in which MER practices were reflected by the perceptions of individual project participants. In the questionnaire survey, only on-site project participants who were directly involved in MER practices were considered as targeted 
respondents. These respondents were senior and professional individuals (with knowledge of MER practices), including project owners, contractors, and consultants.

This paper adopted a stakeholder-oriented conceptualization of MER practices, which refers to "megaproject environmental initiatives taking into account the interests of different stakeholder groups, including governments/owners, non-owner stakeholders (i.e., contractors, consultants, designers, and suppliers), the local community, as well as the general public" (Zeng et al., 2015). MER practices directed toward the four abovementioned stakeholder groups manifest themselves in very different ways. To better explain and predict OCBEs, it is necessary to distinguish how project participants perceive the four types of MER practices. These considerations lead to the following research question:

How do project participants' perceptions of MER practices directed towards the four stakeholder groups affect their environmental commitment and, in turn, their OCBEs?

This paper is organized as follows. Section 2 provides the theoretical foundations and presents the research hypotheses based on a literature review. Section 3 illustrates the research methods and analytical procedures. Section 4 presents the data analysis results. Section 5 discusses the research findings and their implications for megaproject environmental management. Section 6 summarizes the key ideas and suggests a research agenda.

\section{Theoretical foundation and hypotheses}

\subsection{Defining OCBEs in megaprojects}

Recent research findings make a convincing case to include voluntary pro-environmental behaviors as part of the "organizational citizenship behaviors" (OCBs) domain—otherwise known as organizational citizenship behaviors for the environment (OCBEs) (Boiral, 2009; 
Daily et al., 2009; Raineri and Paillé, 2016). Inspired by the taxonomy of OCBs proposed by Organ et al. (2006), Boiral and Paillé (2012) further classified OCBEs into five categories - helping, sportsmanship, organizational loyalty, individual initiative, and self-development. On this basis, the possible applications of OCBEs and their natures in megaprojects are discussed as follows:

Helping includes altruism with regard to environmental protection and collaboration to promote environmental initiatives. The megaproject is characterized by a high level of uncertainty (Van Marrewijk et al., 2008). It has ambiguous role boundaries and must rely on project participants to make a concerted effort to achieve environmental goals, e.g., helping colleagues to better understand project environmental goals and encouraging them to adopt more environmentally conscious behaviors or to express their ideas and opinions on environmental issues. Consequently, helping behaviors can be viewed as a common cooperative effort to improve the environmental performance of a megaproject (Invernizzi et al., 2016).

Sportsmanship refers to the tolerance of and positive attitude toward the inconveniences and additional work that can be associated with environmental practices, e.g., willingness to make time to support the project environmental department when unexpected environmental problems occur (e.g., extreme climate events). Megaprojects are carried out under conditions of high complexities (Locatelli et al., 2014) and face huge environmental risks (Flyvbjerg et al., 2003). Considering the complexity and diversity of the environmental problems in megaprojects (Zeng et al., 2015), addressing these problems requires not only a rapid response by the project environmental department, but also the prompt assistance of project 
111

112

113

participants working in other departments (e.g., safety, quality, and labor departments).

Organizational loyalty means the day-to-day adherence to environmental policies and goals, e.g., voluntary compliance with the formal and informal (i.e., both stated and unwritten) project environmental policies and procedures. Megaprojects bring together differing and competing stakeholders, interests, and values (Locatelli and Mancini, 2012a; Ruuska et al., 2011; Van Marrewijk et al., 2008). More often than not, the success of environmental management practices is based on the discretionary adherence of multi-stakeholders to the overarching environmental goals (Daily et al., 2009).

Individual initiative is based on personal involvement and participation in environmental activities, e.g., making suggestions to minimize construction wastes and providing early warnings to prevent on-site pollution accidents. Creativity is perceived to be an essential ingredient for ensuring the success of a megaproject (Maier and Branzei, 2014). The goal of this dimension is to facilitate the improvement of overall environmental performance by stimulating the proactive and innovative initiatives of project participants.

Self-development involves the development of personal knowledge with respect to environmental protection. The roles of knowledge transfer and self-learning have been recognized as crucial for improving organizational adaptabilities, especially in complex megaprojects (Van Marrewijk et al., 2008). There are two approaches to self-development-active participation in project training programs (e.g., environmental protection lectures) and the effective acquisition of environmental information through self-learning during the course of daily work activities. 


\subsection{The relationship between environmental commitment and OCBEs}

According to Meyer and Herscovitch (2001), environmental commitment is a frame of mind that denotes a sense of both attachment and responsibility to the environmental targets of an organization. Through the lenses of reasoned action theory (Ajzen and Fishbein, 1980) and value-belief-norm theory (Stern et al., 1999), specific attitudes that are either context-dependent or have behavioral direction are more likely to be enacted and reified (Raineri and Paillé, 2016). With the growing concern about environmental issues, the positive environmental performance of a megaproject may lead project participants to feel increased levels of self-esteem and to recognize the environmental values of the project in which they play a part. The environmental commitment engendered by project environmental practices can make participants feel that they share environmental values with other project participants. As such, they are more likely to engage in discretionary extra-role behaviors (e.g., OCBEs) that benefit other project participants. In addition, they may tend to devote additional efforts to meeting the environmental goals of the project. Based on the above, the following hypothesis is proposed:

H1. The environmental commitment of project participants is positively related to their OCBEs.

\subsection{Impact of project participant perceptions of MER practices on their} environmental commitment and OCBEs

\subsubsection{Taxonomy of MER practices}

Environmental responsibility, an important and distinct component of corporate social responsibility (CSR), is typically seen as a set of environment-friendly practices intended to 
154

155

positively affect stakeholders (Rahman and Post, 2012). The stakeholders of a megaproject are those who affect or are affected by project practices, including both internal stakeholders (i.e., owners/governments, contractors, consultants, designers, and suppliers) and external stakeholders (i.e., the local community and general public) (Zeng et al., 2015).

Considering the differences between project roles, internal stakeholders can be further divided into two types: 1) governments (i.e., regulators and owners) and 2) non-owner stakeholders (i.e., contractors, consultants, designers, and suppliers). Governments, which typically initiate megaprojects, play a dual role that incorporates supervision (in terms of laws and regulations) and participation (in terms of project contracts). In contrast, contractors, consultants, designers, and suppliers are linked only through project contracts. Similarly, external stakeholders can also be classified into two categories: 1) the local community and 2) the general public (Zeng et al, 2015). The local community is directly affected by the implementation process of megaprojects, e.g., land expropriation, housing demolition, as well as changes in property values and living environments. Apart from the local community, other external stakeholders are included in the general public category.

Through the lens of social identity theory (SIT), membership in different social categories is considered to convey social identity that defines one's attributes as a member of that group (Ashforth and Mael, 1989). Specifically, one's social identity provides benchmarks by which people can know what they should feel and think, as well as how they should behave. The term corporate organization can be viewed as a social categorization (Turker, 2009b). According to Newman et al. (2015), when employees view their organization as socially responsible, organizational identification processes will promote extra-role behaviors that 
augment the employer's CSR practices. With respect to a megaproject, the project-based organization serves as a social categorization of its participants. According to SIT, and in combination with insights from Newman et al. (2015), this study argues that project participants' perceptions of MER practices can motivate their engagement in OCBEs as a function of project identification processes that promote pride in and attachment to the environmental goals and values of the project. As such, this paper proposes Hypotheses 2, 3, 4 , and 5 in the next sections.

\subsubsection{MER practices directed toward governments}

The first group of selected stakeholders is governments. The compliance of a megaproject with the environmental obligations pursuant to laws, regulations, and contracts is likely to be viewed in a positive light. This is due to the megaproject's high degrees of uncertainty and complexity (Van Marrewijk et al., 2008). It is notable that this tendency leads megaproject participants to develop high levels of self-esteem and to identify themselves with the environmental values of the project. According to SIT, and based on insights from the OCBs literature (Carmeli et al., 2007; Newman et al., 2015), MER practices directed toward governments (MER-G) encourage project participants to exert further effort to achieve project environmental goals and to transcend their job roles to assist others whom they perceive as having similar environmental values. On this basis, the following hypotheses are presented:

H2a. Project participants' perceptions of MER-G are positively related to their environmental commitment.

H2b. Project participants' perceptions of MER-G are positively related to their OCBEs. 


\subsubsection{MER practices directed toward non-owner stakeholders}

Environmental responsibility directed toward non-owner stakeholders, e.g., contractors, consultants, designers, and suppliers, may manifest in a variety of ways. Such manifestations include suitable on-site working and living environments, commitments to justice in dealing with environmental issues, and opportunities for the development of environmental knowledge and skills. When project participants perceive that a megaproject meets their personal environmental needs and those of their colleagues, they are likely to perceive that the megaproject shares environmental values similar to their own. Through the lenses of SIT and the literature on OCBs (Newman et al., 2015; Zhang et al., 2014), MER practices directed toward non-owner stakeholders (MER-N) make project participants more likely to engage in discretionary extra-role behaviors (e.g., OCBEs) that benefit others involved in the project and to exert additional efforts to achieve project environmental goals. Given this finding, the following hypotheses are presented:

H3a. Project participants' perceptions of MER-N are positively related to their environmental commitment.

H3b. Project participants' perceptions of MER-N are positively related to their OCBEs.

\subsubsection{MER practices directed toward the local community}

Megaprojects substantially alter regional ecological environments and local communities are among the first to be affected. Consistent with SIT and previous OCBs research (Bartels et al., 2010; Newman et al., 2015), project participants are likely to show an interest in environmental activities, as well as to identify with the environmental values of the project, if the megaproject receives positive feedback from the local community regarding its 
environmental practices. Therefore, MER practices directed toward the local community (MER-L) are likely to foster feelings of a shared environmental commitment and responsibility on the part of project participants, thereby leading them to exert additional effort to meet project environmental goals, perform at a high level, and engage in discretionary OCBEs. All of the above reasoning suggests the following hypotheses:

H4a. Project participants' perceptions of MER-L are positively related to their environmental commitment.

H4b. Project participants' perceptions of MER-L are positively related to their OCBEs.

\subsubsection{MER practices directed toward the general public}

Environmental responsibility directed toward the general public refers to the eco-friendly philosophy of megaproject managers and their targeted measures for secondary (i.e., indirect and external) stakeholders. Based on SIT and the OCBs literature (Bartels et al., 2010; Newman et al., 2015), when a megaproject undertakes environmental measures that benefit the whole society (even at the risk of budget overruns or schedule delays), this tends to build a sense of environmental commitment on the part of project participants via identification with and adherence to the environmental goals of the project. Moreover, this outcome may lead to the project participants and their colleagues feeling that they possess similar attributes and shared values. Rather than simply focusing on achieving their own goals, MER practices directed toward the general public (MER-P) cause project participants to be more likely to engage in risky discretionary behaviors that benefit others (e.g., OCBEs). Thus, the following hypotheses are developed:

H5a. Project participants' perceptions of MER-P are positively related to their environmental 
commitment.

H5b. Project participants' perceptions of MER-P are positively related to their OCBEs.

\subsection{Control variables}

To isolate the variations within the organizational and project contexts (Cao et al., 2017), four control variables were included in the analysis of the relationships between project participants' perceptions of MER practices and their OCBEs. As the first control variable, project role was operationalized as a dummy variable reflecting whether or not the surveyed respondents were owners $(0=$ yes; $1=$ no $)$. With regard to the remaining three control variables, project size was measured by the investment value of the surveyed project $(1=$ below CNY 500 million; 2 = between CNY 500 and 1000 million; $3=$ between CNY 1000 and 5000 million; 4 = between CNY 5000 and 10000 million; 5 = above CNY 10000 million); project type was measured as a dummy variable indicating whether or not the surveyed project is a basic infrastructure $(0=$ basic infrastructure; $1=$ non-basic infrastructure $) ;{ }^{1}$ and project duration was measured by the construction period of the surveyed project $(1=$ less than 24 months; $2=$ between 24 and 36 months; $3=$ between 36 and 48 months; $4=$ between 48 and 60 months; $5=$ more than 60 months).

\section{Research methods}

\subsection{Questionnaire design}

This study used a questionnaire survey to collect primary data. This questionnaire was designed and developed with the support of literature reviews, project observations, and

\footnotetext{
${ }^{1}$ Basic infrastructures refer to energy, transportation, and communications projects that provide fundamental and essential services for social production and everyday life. Non-basic infrastructural megaprojects, e.g., skyscrapers, exhibition facilities, and industrial parks, provide specialized value-added services for culture, business, and so on.
} 
261

262

263

265

266

267

semi-structured explorative interviews conducted prior to the survey. ${ }^{2}$

The construct environmental responsibility is derived from CSR to reflect an organization's social performance in dealing with environmental issues. As such, the environmental responsibility section of the questionnaire was initially adapted from CSR measurement items (Turker, 2009a). This kind of measurement adaptations has been validated over a large spectrum of organizations and industries (De Roeck and Delobbe, 2012; Ho et al., 2012; Sparks et al., 2013).

In this study, environmental responsibility items with respect to the general public (including NGOs), the local community, non-owner stakeholders, and governments were adapted based on CSR constructs related to society, customers, ${ }^{3}$ employees, and the government, respectively. All 18 related measurement items in Turker's (2009a) CSR scale were modified to suit the environmental management perspective in the megaproject context. Moreover, these items were further refined and validated through a series of interviews with researchers and practitioners who have extensive experiences in megaproject management.

With respect to environmental commitment (EC), seven measurement items were adapted from Raineri and Paillé (2016) to reflect project participants' sense of attachment to environmental concerns in the megaproject. As for OCBEs, seven measurement items developed by Boiral and Paillé (2012) were used to reflect how project participants initiated innovative and spontaneous behaviors directed at environmental improvement. All the OCBEs items were integrated into a construct to better understand the relationships between

\footnotetext{
${ }^{2}$ The four interviewed project managers from a large construction consulting corporation have engaged in several influential megaprojects in China, e.g., Shanghai World Expo, Shanghai Disney Resort, and Suzhou-Nantong Bridge. The two interviewed professors from Tongji University have conducted megaproject research for over 15 years.

${ }^{3}$ Construction projects are typically operated through the "production-to-order" system, with the aim to meet the demands of clients (Cao et al., 2014). Local communities are the primary users of megaprojects and play a role analogous to that of "customers" who are directly affected by the "product" (i.e., the megaproject).
} 
281

282

project participants' perceptions of MER practices and their overall OCBEs performance.

The measurement items developed by Raineri and Paillé (2016) and Boiral and Paillé (2012) were selected in this study because they are relatively general and therefore applicable to a variety of organizations, activity sectors, occupations, and/or circumstances. Similarly, EC and OCBEs items were also refined and contextualized after the rounds of interviews.

All the abovementioned variables were operationalized as reflective constructs. Appendix A shows the measurement items in detail. These measurement items were rated on a five-point scale ranging from 1 (strongly disagree) to 5 (strongly agree). Although the questionnaire was originally developed in English, it was subsequently translated into Chinese to facilitate the respondents' comprehension. This study employed the back-translation technique to establish linguistic equivalence between the two versions.

\subsection{Participants and procedures}

A pre-test involving 23 megaproject professionals ${ }^{4}$ was conducted to identify ambiguous expressions and to test the validity of the related constructs in the questionnaire. In view of the feedback from those pre-test respondents, the questionnaire was further revised. For example, the expression "environmental impacts" in the environmental responsibility item "Our project implements green and low-carbon technologies to mitigate the environmental impacts" was rephrased to "negative environmental impacts" in the questionnaire.

The survey was conducted from November 2015 to March 2016 in China. After contacting the megaproject owners, ${ }^{5}$ the project departments and participants involved in MER practices were preliminarily identified for this survey. There was a short communication prior to the

\footnotetext{
${ }^{4}$ The 23 pre-test respondents were senior and professional individuals with jobs related to construction environmental management (e.g., environmental training and supervision). They were familiar with environmental codes, laws, and project policies; and all had more than five years of experiences in megaproject management.

${ }_{5}$ Megaproject owners refer to project-specific owner companies, e.g., Shanghai World Expo (Group) Co., Ltd.
} 
302

303

formal questionnaire survey. The respondents were informed of the survey purpose, assured of the data confidentiality, and offered small gifts ${ }^{6}$ for completing the questionnaire.

With the support of the megaproject owners, the questionnaire was distributed to the targeted respondents. To improve the representativeness of the surveyed samples, this study distributed the questionnaire to respondents from different megaprojects and to those who had assumed different roles in MER practices. In this survey, respondents were asked to complete the questionnaire based on their most recently experienced megaproject. In consequence, respondents provided a relatively clear description of the projects' environmental practices and thereby avoided preferentially selecting their most successful experience with environmental protection, which ultimately reduced the risk of socially desirable responding (SDR). According to Milfont (2009), SDR has little impact on the way people answer questions related to their environmental attitudes and ecological behaviors in anonymous questionnaires. For these reasons, SDR effect is limited in this survey.

In addition, to further determine the respondents' perceptions of their projects' environmental practices, this survey included the question "Are you familiar with the project's environmental policies and measures?," with the options of "Yes," "No," or "Unsure." The inclusion of the "Unsure" option was based on the work of Norton et al. (2014) to prevent respondents from having to make a forced-choice response. Finally, only the respondents who provided a conclusive answer of "Yes" were retained, while the "No" or "Unsure" answers were discarded as invalid responses. After omitting invalid responses and deleting outliers, a total of 172 completed questionnaires were ultimately included in the

\footnotetext{
${ }^{6}$ Each of the participants was given a set of souvenirs (i.e., notepad, gel pen, and bookmark) with the Tongji logo or a cash gift
} through WeChat. 
323

324

subsequent analysis. Of the 172 respondents, $58(33.72 \%)$ were senior managers (i.e., project managers), $70(40.70 \%)$ were middle managers (i.e., department managers and professional executives), and 44 (25.58\%) worked at the operational level (i.e., project engineers).

Table 1 shows the demographic characteristics of the surveyed projects and associated respondents. Of the 172 valid responses, $41.28 \%$ were collected via on-site visits and the remaining $36.63 \%$ and $22.09 \%$ were collected via a survey system (http://www.sojump.com) and e-mails, respectively. An analysis of variance (ANOVA) ${ }^{7}$ indicates that no statistically significant differences exist in the answers from the three response groups (p-values ranged from 0.118 to 0.861$)$.

$<$ Insert Table 1>

\subsection{Tools for data analysis}

In this study, factor analysis (FA) was used to analyze the collected primary data. FA has been extensively adopted as an effective statistical technique for identifying individual factors that represent sets of interrelated variables (Hon et al., 2013). Exploratory FA with principal component analysis (PCA) makes it possible to identify the underlying grouped factors and to condense the measurement items (He et al., 2016).

To test the hypotheses proposed in Section 2, partial least squares (PLS) technique was employed to develop an estimation method for analyzing the path model (Fig. 1). PLS is a technique that combines PCA, path analysis, and regression to simultaneously estimate multiple dependent variables in a single structural equation model (Ringle et al., 2012).

Of the two structural equation modeling (SEM) approaches, the PLS-SEM was chosen over

${ }^{7}$ ANOVA tests were conducted on the three response groups (on-site visits, survey system, and e-mail); the p-values for MER-P, MER-L, MER-N, MER-G, EC, and OCBEs are 0.643, $0.118,0.861,0.431,0.256$, and 0.601 , respectively. 
the covariance-based SEM method due to the following reasons: (1) it is distribution-free and thus suitable for data from perception-based measurement items of unknown distributions (Aibinu and Al-Lawati, 2010); (2) it works efficiently with small sample sizes (Hair et al., 2014), whereas covariance-based SEM considers 200 to be the critical sample size for accurate assessments of model fits (Hoelter, 1983); (3) it avoids factor indeterminacy by estimating constructs as exact linear combinations of the measurement items (Hair et al., 2011); and (4) it is most appropriately applied in early-stage theory development and testing (Astrachan et al., 2014), which fits well with the exploratory nature of this study. Indeed, PLS-SEM has enjoyed steady popularity as a key multivariate analysis method in the study of cooperative behaviors (Aibinu et al., 2008), relational behaviors (Ning and Ling, 2013), environmental behaviors (Yusof et al., 2016), and organizational citizenship behaviors (Lim and Loosemore, 2017) in construction projects.

\section{Data analysis and results}

\subsection{Factor analysis}

In this study, FA was employed to investigate 18 items related to MER practices. The Kaiser-Meyer-Olkin $(\mathrm{KMO})$ value is $0.927>0.6$, thereby indicating excellent sample adequacy (Field, 2009). In addition, Bartlett's test of sphericity (BTS) produced an approximation of $\chi^{2}=2131.110(\mathrm{df}=153, \mathrm{p}=0.000<0.001)$, which suggests that the correlations between variables are sufficiently strong to conduct PCA (George, 2003). As expected, the FA analysis extracted four factors reflecting the MER-P, MER-L, MER-N, and MER-G constructs. Table 2 shows that the rotated loadings of the manifest items with regard to their intended constructs are all above the recommended threshold of 0.5 and are greater 
than the loadings on other constructs. These results validate the appropriateness of using the 18 listed MER items to reflect the four proposed constructs. Similarly, FA procedures were also applied to extract measurement items for EC and OCBEs. And no EC or OCBEs items were removed from the measurement model.

\section{$<$ Insert Table 2>}

\subsection{Evaluation of the measurement models}

The validity of all measurements was further assessed in terms of internal consistency, convergent validity, and discriminant validity. Internal consistency was assessed by estimating the composite reliability. Table 3 shows that the composite reliability values are all greater than 0.7 , thereby indicating a satisfactory reliability level of the internal indicators for each construct (Hair et al., 2011). Convergent validity measures the extent to which the items underlying a particular construct actually represent this conceptual variable. Initial evidence of convergent validity was reflected by the values of the average variance extracted (AVE). Table 3 shows that the AVE values are all greater than 0.5 , thereby suggesting a satisfactory level of convergent validity of the constructs (Hair et al., 2011). Further evidence of convergent validity was provided by the factor loadings of each measurement item. The standardized factor loadings of all the respective constructs of the items are above the threshold of 0.7 and there was no evidence of any cross-loading problem (Table 4). In addition, the square roots of AVE (i.e., values on the diagonal of the correlation matrix in Table 3) are all greater than the absolute value of the inter-construct correlations (i.e., off-diagonal values), which indicates that the constructs have satisfactory discriminant validity. 
Harman's single-factor test was used to analyze the possibility of common method bias. The test results reveal no single dominant factor, with the largest factor accounting for only $14.72 \%^{8}$ of the total measurement variances. Therefore, common method bias is limited in this survey.

\subsection{Comparative analysis}

The respondents had a mix of project roles, including $41.86 \%$ project owners, $35.47 \%$ contractors, and $22.67 \%$ consultants (Table 1). Compared with project owners and consultants, contractors had more direct experiences in the implementation of project environmental initiatives and provided more positive feedback on MER practices, as shown in Table 5. However, ANOVA test results indicate that none of these differences are statistically significant at the $5 \%$ level (p-values range from 0.125 to 0.758 ). Furthermore, the ANOVA test for OCBEs reveals no significant difference in environmental-behavior-related decision making between project owners, contractors, and consultants. All these results provide evidence that differences in project roles have insignificant impacts on the surveyed respondents' perceptions of MER practices and their OCBE performance.

\section{$<$ Insert Table 5 $>$}

\subsection{Hypothesis testing and results analysis}

To compute standard errors and test the statistical significance of the path coefficients, a bootstrapping procedure with 5,000 resamples was performed (Fig. 1). The $\mathrm{R}^{2}$ value of the

\footnotetext{
${ }^{8}$ Harman's one-factor test was performed for both independent and dependent variables (MER-P, MER-L, MER-N, MER-G, $\mathrm{EC}$, and OCBEs) and for four control variables. The five largest factors account for $14.72 \%, 13.25 \%, 12.92 \%, 12.25 \%$, and $7.76 \%$ of the total variances.
} 
dependent variable (i.e., OCBEs) is 0.459 , thereby suggesting that most of the variances in the construct are explained by the research model. Figure 1 shows that the influence of EC on OCBEs is significant $(\beta=0.239, \mathrm{p}<0.01)$; thus, Hypothesis 1 is supported. The results of the bootstrapping analysis also indicate that the MER-G-EC link $(\beta=0.158, \mathrm{p}<0.05)$, MER-N-EC link $(\beta=0.349, \mathrm{p}<0.001)$, MER-L-EC link $(\beta=0.175, \mathrm{p}<0.01)$, and MER-P-EC link $(\beta=0.233, \mathrm{p}<0.01)$ are all significant, thereby providing evidence supporting Hypotheses 2a, 3a, 4a, and 5a, respectively.

$$
<\text { Insert Fig. 1 }>
$$

Regarding the relationships between MER practices and OCBEs, only the influences of project participants' perceptions of MER practices directed toward internal stakeholders (i.e., MER-G and MER-N) are found to be significant when the effect of EC is included ( $\beta=0.181$, $\mathrm{p}<0.05 ; \beta=0.218, \mathrm{p}<0.05)$. Thus, Hypotheses $2 \mathrm{~b}$ and $3 \mathrm{~b}$ are supported. Together with the significant links between MER-G and EC and between EC and OCBEs, this finding further indicates that the influence of MER-G on OCBEs is partially mediated by EC. A similar conclusion is also reached for MER-N.

To further investigate the effects of project participants' perceptions of MER practices on their OCBEs, an alternative model without the mediator was tested. Figure 2 presents the PLS analysis results for the alternative research model. Although the intermediating effect of EC is excluded, the direct influences of MER-L and MER-P on OCBEs are still insignificant. Therefore, Hypotheses $4 \mathrm{~b}$ and $5 \mathrm{~b}$ are not supported by the data. In addition, with regard to the control variables, project duration, project type, project role, and project size, all exert insignificant influences on OCBEs in both models. 


\section{Discussion and implications}

433

434

435

\subsection{Discussion of findings}

Currently, unprecedented levels of urbanization have led to massive government-financed megaprojects in China. With the emergence of newly built, restructured, or expanded megaprojects, environmental issues have become increasingly prominent and have aroused considerable concerns among megaprojects managers. The success of megaproject environmental management lies in the willingness of project participants to support continuous change and take responsibility for environmental protection on a discretionary basis. Therefore, OCBEs play an important role in improving the efficiency of megaproject environmental practices, specifically through the development of preventive approaches that call for the voluntary commitment of project participants to environmental protection.

Different types of environmental responsibility practices affect OCBEs differently. The project participants' perceptions of MER-N emerge as the principal predictor of their OCBEs, with a path coefficient of 0.292 (Fig. 2). Such a strong link between MER-N and OCBEs was expected at the beginning of the survey, because the related items are all closely connected with the respondents' rights and interests, e.g., working conditions, training opportunities, and procedural equalities. According to Maslow's hierarchy of needs, the MER-N practices in megaprojects fill a high-order need for individual self-actualization. Establishing environmental management systems (e.g., ISO 14000) and introducing green technologies have become increasingly popular in megaprojects, whereas there are few incentives for megaprojects to invest in "soft areas" (i.e., human considerations). The empirical results of 
the current study provide evidence that MER-N practices are perhaps implemented to reap organizational rewards for promoting project participants' OCBEs. Although the initial investments in human capital and training may be unattractive to megaproject managers, continuous MER-N efforts are likely to pay off over the long term by eliciting high levels of EC among project participants.

Project participants' perceptions of MER-G emerge as the second principal predictor of their OCBEs, with a path coefficient of 0.222 (Fig. 2). Interestingly, the effect of MER-G on EC and OCBEs is inconsistent with the findings of previous research. In particular, Turker (2009b) determined that employees' perceptions of CSR practices directed toward governments are insignificant factors affecting their organizational commitment. Meanwhile, Newman et al. (2015) argued that employees' perceptions of CSR practices directed toward governments do not result in high levels of OCBs. The findings of the current study may be explained by the dual governmental roles. In China, most megaprojects are initiated by the central or local governments while also involving environmental supervisory departments (e.g., the Ministry of Environmental Protection) (Zeng et al., 2015). Therefore, governments have partially achieved a role transition in megaprojects from external supervisors to internal stakeholders (i.e., owners). MER-G practices are expected to meet both the legal requirements of regulators and the contractual agreements with owners. Megaprojects in China that perform MER-G practices are likely to be considered significant endeavors due to the complexity and diversity of the environmental issues. This perspective might lead project participants who work for such megaprojects to develop high levels of self-esteem and to identify with the environmental values of the project. 
Project participants' perceptions of MER-L and MER-P represent the least significant set of predictors of their OCBEs. Interestingly, the effects of MER-L and MER-P on OCBEs, as determined in this study, also differ from those of prior empirical studies. As noted by Newman (2015), employees' perceptions of CSR directed toward social and nonsocial stakeholders (e.g., the local environment and general public) strongly influenced their OCBs. The results of the current study may be related to the essential mission of megaprojects. Megaprojects are committed to providing fundamental public services that benefit local communities and, consequently, the country in general. The ecological protection of the local natural environment is the primary objective of megaprojects. Thus, the more the project participants take MER-P or MER-L for granted, the more ineffective they will perceive it to be. This perspective might lead project participants to respond less positively to MER-P or MER-L than to MER-G and MER-N practices.

Although MER-P and MER-L practices have received considerable attention, megaprojects have not demonstrated ideal environmental performance. In the course of preliminary interviews with megaproject managers, several interviewees were skeptical about the real effectiveness of MER-P and MER-L practices. Some MER-P and MER-L practices are little more than environmental slogans and have yet to achieve their expected goals. For example, an interviewee with more than 15 years of experience in managing megaprojects indicated that "a substantial part of the MER-P and MER-L practices are more often established to gain a better social reputation rather than to improve actual environmental performance or project participants' environmental skills"-otherwise known as "green-washing." In this regard, "green-washing" appears to be the external projection of a positive image of a 
megaproject that is not reflected in its internal initiatives regarding environmental issues (Testa et al., 2015). On this basis, a megaproject's MER-P and MER-L practices are unlikely to engender high levels of project identification or to subsequently affect OCBEs.

\subsection{Implications}

This study makes several contributions to the fields of megaproject management, environmental responsibility, and OCBs. First, it extends previous research on the environmental citizenship in permanent corporate organizations and the OCBs in temporary project organizations by providing further insights into the mechanisms underlying project participants' willingness to sustain and support the environmental efforts of megaprojects. Although most previous studies have tended to consider environmental responsibility, the current study shows that MER practices directed toward the four groups of stakeholders account for the unique variance at the EC level, thereby affecting OCBEs differently. The analysis of empirical data supports the claim of Raineri and Paillé (2016) that EC plays a pivotal role in connecting organizational environmental practices with OCBEs. However, this study indicates that OCBEs are only positively related to project participants' perceptions of MER practices directed toward internal stakeholders, whereas these behaviors have no significant association with MER practices directed toward external stakeholders.

Slogan propaganda, which highlights concerns related to the local community and general public, is often posited as an effective approach for enhancing individual awareness of environmental issues and promoting their participation in environmental protection. Although the findings of the current study confirm this key role, macro-policy advocacy is insufficient for encouraging the pro-environmental behaviors of project participants. Megaproject 
managers should be aware of the priority to improve MER practices directed toward internal stakeholders. They should also provide project participants with increased opportunities to access environmental training and to obtain equal rights in expressing environmental appeals. MER practices directed toward external stakeholders have often been described as "a means of increasing social reputation" in megaprojects. In the implementation process of project environmental policies, establishing clear goals and supportive measures is a method by which to avoid confusion on the part of project participants regarding the goal of MER practices. Initiatives aimed at improving environmental performance should be accompanied by effective internal communication and project participants' involvement in environmental practices to ensure their positive perceptions of MER practices.

Secondly, this study is novel as it investigated how the principal dimensions of OCBs could be applied to the environmental practices of megaprojects. Successful environmental practices are linked with the input of a multitude of social, economic, and technical elements that cannot be entirely covered by prescribed tasks (Locatelli and Mancini, 2012b). Daily et al. (2009) indicated that the success of environmental practices may hinge on individual behaviors that are beyond the scope of formal contractual systems. Therefore, extra-role OCBEs are necessary to promote the implementation of formal management systems and to compensate for their deficiencies, facilitate tacit knowledge sharing, and stimulate collaboration in dealing with environmental issues (Boiral, 2009). OCBEs do not underestimate the value of formal management practices or undermine the establishment of considerably robust management systems, but can co-exist with formal environmental methods. Building an integrated and reasonable system of rewards and punishments that go 
541 beyond contractual agreement is necessary to encourage the emergence of OCBEs.

542

543

544

545

546

547

548

549

550

551

552

553

554

555

556

557

558

559

560

561

562

\section{Conclusions}

OCBEs are constituted by individual, informal, and discretionary behaviors that contribute greatly to the efficiency of environmental practices. Prior studies on environmental management have overlooked the key role of OCBEs in megaprojects. However, megaproject managers have realized their importance in dealing with the increasing challenges of environmental management, e.g., the complexity of environmental issues, the deficiencies of formal management systems, the need to consider tacit knowledge, the significance of helping relationships, and the promotion of the environmental legitimacy of projects. Under the increasing pressures to ensure environmental protection, project participants become considerably aware of environmental issues during the implementation of megaprojects. The research presented in this paper takes an SIT perspective and addresses how project participants' perceptions of MER practices directed toward four stakeholder groups influence their EC and OCBEs.

The strong link between project participants' perceptions of MER practices and their EC indicates that investments in environmental responsibility practices, particularly those directed toward internal stakeholders, yield significant benefits. This paper also clarifies how MER practices directed toward the four stakeholder groups could be used to effectively stimulate the emergence of OCBEs in megaprojects. If they are to foster the widespread "buy-in" of project participants, MER practices should be genuine (i.e., internalization) as opposed to symbolic (i.e., "green-washing"). With this perspective, internalization refers to the substantive rather than superficial integration of specific practices and principles proposed 
by MER in daily project activities.

Despite its valid contributions, this study has limitations and open questions that call for future research. Firstly, this study focused on China's megaprojects. Although some of these are international megaprojects (e.g., Shanghai World Expo and Shanghai Disney Resort), this sampling technique limits the generalizability of research findings with respect to other geographic contexts. Considerable variance in terms of MER practices in different geographical contexts might amplify the significance of research findings.

Secondly, after analyzing the social-psychological processes (i.e., antecedents) leading project participants to engage in OCBEs, a natural extension of the current study would be to investigate the consequences (or impacts) of OCBEs. Specifically, future studies could address how different OCBEs categories at the project-level-including helping, sportsmanship, organizational loyalty, organizational compliance, individual initiative, and self-development—make an impact on project environmental performances.

Thirdly, leadership has been recognized as one of the most critical factors influencing the emergence of OCBEs. However, it remains unclear which leadership styles are most suitable in fostering project participants' OCBEs. Future research could explore these relationships and bridge the gap between emerging OCBE research and more established literature based on leadership theory (e.g., transformational and transactional leadership) and environmental management.

\section{Conflict of interest}

There is no conflict of interest. 


\section{Acknowledgments}

This work was supported by the National Natural Science Foundation of China (Project No.: 71571137, 71471136 and 71390523) and the International Exchange Program for Graduate Students of Tongji University. The authors are very grateful to the anonymous referees that provide valuable suggestions. The authors are also grateful to Yongkui Li, Yujie Lu, Jianxun Xie, Lan Luo, Shuang Dong, Ju Bai, Delei Yang, Zhen Chen, Dongping Cao, Diletta Colette Invernizzi, Yanhong Ma, and Pei Tong for their comments on the preliminary versions of this paper.

\section{Reference}

Aibinu, A. A., Ofori, G., \& Ling, F. Y., 2008. Explaining cooperative behavior in building and civil engineering projects' claims process: Interactive effects of outcome favorability and procedural fairness. Journal of Construction Engineering and Management, 134 (9), 681-691.

Aibinu, A. A., \& Al-Lawati, A. M., 2010. Using PLS-SEM technique to model construction organizations' willingness to participate in e-bidding. Automation in Construction, 19(6), 714-724.

Ajzen, I., \& Fishbein, M., 1980. Understanding attitudes and predicting social behaviour. Prentice-Hall, Englewood Cliffs, New Jersey.

Ashforth, B. E., \& Mael, F., 1989. Social identity theory and the organization. Academy of Management Review, 14(1), 20-39.

Astrachan, C. B., Patel, V. K., \& Wanzenried, G., 2014. A comparative study of CB-SEM and PLS-SEM for theory development in family firm research. Journal of Family Business Strategy, 5(1), $116-128$.

Bartels, J., Peters, O., de Jong, M., Pruyn, A., \& van der Molen, M., 2010. Horizontal and vertical communication as determinants of professional and organisational identification. Personnel Review, 39(2), 210-226.

Boiral, O., 2009. Greening the corporation through organizational citizenship behaviors. Journal of Business Ethics, 87(2), 221-236.

Boiral, O., \& Paillé, P., 2012. Organizational citizenship behaviour for the environment: Measurement 
and validation. Journal of Business Ethics, 109(4), 431-445.

Boiral, O., Talbot, D., \& Paillé, P., 2015. Leading by example: A model of organizational citizenship behavior for the environment. Business Strategy and the Environment, 24(6), 532-550.

Boiral, O., Raineri, N., \& Talbot, D., 2016. Managers' Citizenship Behaviors for the Environment: A Developmental Perspective. Journal of Business Ethics, 1-15.

Braun, T., Ferreira, A. I., \& Sydow, J., 2013. Citizenship behavior and effectiveness in temporary organizations. International Journal of Project Management, 31(6), 862-876.

Brookes, N. J., \& Locatelli, G., 2015. Power plants as megaprojects: Using empirics to shape policy, planning, and construction management. Utilities Policy, 36, 57-66.

Cao, D., Li, H., \& Wang, G., 2014. Impacts of isomorphic pressures on BIM adoption in construction projects. Journal of Construction Engineering and Management, 140(12), 04014056.

Cao, D., Li, H., Wang, G., \& Huang, T., 2017. Identifying and contextualising the motivations for BIM implementation in construction projects: An empirical study in China. International Journal of Project Management, 35(4), 658-669.

Daily, B. F., Bishop, J. W., \& Govindarajulu, N., 2009. A conceptual model for organizational citizenship behavior directed toward the environment. Business \& Society, 48(2), 243-256.

Carmeli, A., Gilat, G., \& Waldman, D. A., 2007. The role of perceived organizational performance in organizational identification, adjustment and job performance. Journal of Management Studies, 44(6), 972-992.

De Roeck, K., \& Delobbe, N., 2012. Do environmental CSR initiatives serve organizations’ legitimacy in the oil industry? Exploring employees' reactions through organizational identification theory. Journal of Business Ethics, 110(4), 397-412.

Ekrot, B., Rank, J., \& Gemünden, H. G., 2016. Antecedents of project managers' voice behavior: The moderating effect of organization-based self-esteem and affective organizational commitment. International Journal of Project Management, 34(6), 1028-1042.

Field, A., 2009. Discovering statistics using SPSS. Sage, London.

Flyvbjerg, B., Bruzelius, N., \& Rothengatter, W., 2003. Megaprojects and risk: An anatomy of ambition. Cambridge University Press, Cambridge.

Flyvbjerg, B., 2014. What you should know about megaprojects and why: An overview. Project Management Journal, 45(2), 6-19. 
641 George, D., 2003. SPSS for windows step by step: A simple study guide and reference, 17.0 update, 642 10/e. Pearson Education India, Delhi.

643 Hair, J. F., Ringle, C. M., \& Sarstedt, M., 2011. PLS-SEM: Indeed a silver bullet. Journal of Marketing 644 Theory and Practice, 19(2), 139-152.

645 Hair, J. F., Hult, G. T. M., Ringle, C. M., \& Sarstedt, M., 2014. A Primer on Partial Least Squares

646

Structural Equation Modeling (PLS-SEM). Sage, Thousand Oaks.

Hanisch, B., \& Wald, A., 2014. Effects of complexity on the success of temporary organizations: Relationship quality and transparency as substitutes for formal coordination mechanisms. Scandinavian Journal of Management, 30(2), 197-213.

He, Q. H., Yang, D. L., Li, Y. K., \& Luo, L., 2015. Research on multidimensional connotations of megaproject construction organization citizenship behavior. Frontiers of Engineering Management, 2(2), 148-153.

He, Q., Dong, S., Rose, T., Li, H., Yin, Q., \& Cao, D., 2016. Systematic impact of institutional pressures on safety climate in the construction industry. Accident Analysis \& Prevention, 93, 230-239.

Ho, F. N., Wang, H. M. D., \& Vitell, S. J., 2012. A global analysis of corporate social performance: The effects of cultural and geographic environments. Journal of Business Ethics, 107(4), 423-433.

Hoelter, J. W., 1983. The effects of role evaluation and commitment on identity salience. Social Psychology Quarterly, 140-147.

Hon, C. K. H., Chan, A. P. C., \& Yam, M. C. H., 2013. Determining safety climate factors in the repair, maintenance, minor alteration, and addition sector of Hong Kong. Journal of Construction Engineering and Management, 139(5): 519-528.

Invernizzi, D. C., Locatelli, G., \& Brookes, N., 2016. Managing social challenges in the nuclear decommissioning industry: a responsible approach towards better performance. International Journal of Project Management, http://doi.org/10.1016/j.ijproman.2016.12.002.

Lim, B. T., \& Loosemore, M., 2017. The effect of inter-organizational justice perceptions on organizational citizenship behaviors in construction projects. International Journal of Project Management, 35(2), 95-106.

Locatelli, G., \& Mancini, M., 2010. Risk management in a mega-project: the Universal EXPO 2015 case. International Journal of Project Organisation and Management, 2(3), 236-253.

Locatelli, G., \& Mancini, M., 2012a. Looking back to see the future: Building nuclear power plants in 
Europe. Construction Management and Economics, 30(8), 623-637.

Locatelli, G., \& Mancini, M., 2012b. A framework for the selection of the right nuclear power plant. International Journal of Production Research, 50(17), 4753-4766.

Locatelli, G., \& Mancini, M., 2013. Sustainability in the power plant choice. International Journal of Business Innovation and Research, 7(2), 209-227.

Locatelli, G., Mancini, M., \& Romano, E., 2014. Systems Engineering to improve the governance in complex project environments. International Journal of Project Management, 32(8), 1395-1410.

Locatelli, G., Mariani, G., Sainati, T., \& Greco, M., 2017a. Corruption in public projects and megaprojects: There is an elephant in the room!. International Journal of Project Management, 35 (3), 252-268.

Locatelli, G., Invernizzi, D. C., \& Brookes, N. J., 2017b. Project characteristics and performance in Europe: An empirical analysis for large transport infrastructure projects. Transportation Research Part A: Policy and Practice, 98, 108-122.

Maier, E. R., \& Branzei, O., 2014. “On time and on budget”: Harnessing creativity in large scale projects. International Journal of Project Management, 32(7), 1123-1133.

Meyer, J. P., \& Herscovitch, L., 2001. Commitment in the workplace: Toward a general model. Human Resource Management Review, 11(3), 299-326.

Milfont, T. L., 2009. The effects of social desirability on self-reported environmental attitudes and ecological behaviour. The Environmentalist, 29(3), 263-269.

Newman, A., Nielsen, I., \& Miao, Q., 2015. The impact of employee perceptions of organizational corporate social responsibility practices on job performance and organizational citizenship behavior: Evidence from the Chinese private sector. International Journal of Human Resource Management, 26(9), 1226-1242.

Ning, Y., \& Ling, F. Y. Y., 2013. Reducing hindrances to adoption of relational behaviors in public construction projects. Journal of Construction Engineering and Management, 139(11), 04013017.

Norton, T. A., Zacher, H., \& Ashkanasy, N. M., 2014. Organisational sustainability policies and employee green behaviour: The mediating role of work climate perceptions. Journal of Environmental Psychology, 38, 49-54.

Paillé, P., Boiral, O., \& Chen, Y., 2013. Linking environmental management practices and organizational citizenship behaviour for the environment: a social exchange perspective. The 
International Journal of Human Resource Management, 24(18), 3552-3575.

Paillé, P., Chen, Y., Boiral, O., \& Jin, J., 2014. The impact of human resource management on environmental performance: An employee-level study. Journal of Business Ethics, 121(3), 451-466.

Paillé, P., \& Raineri, N., 2015. Linking perceived corporate environmental policies and employees eco-initiatives: The influence of perceived organizational support and psychological contract breach. Journal of Business Research, 68(11), 2404-2411.

Rahman, N., \& Post, C., 2012. Measurement issues in environmental corporate social responsibility (ECSR): Toward a transparent, reliable, and construct valid instrument. Journal of Business Ethics, 105(3), 307-319.

Raineri, N., \& Paillé, P., 2016. Linking corporate policy and supervisory support with environmental citizenship behaviors: The role of employee environmental beliefs and commitment. Journal of Business Ethics, 137(1), 129-148.

Ringle, C. M., Sarstedt, M., \& Straub, D. W., 2012. Editor's comments: a critical look at the use of PLS-SEM in MIS quarterly. MIS Quarterly, 36(1), iii-xiv.

Ruuska, I., Ahola, T., Artto, K., Locatelli, G., \& Mancini, M., 2011. A new governance approach for multi-firm projects: Lessons from Olkiluoto 3 and Flamanville 3 nuclear power plant projects. International Journal of Project Management, 29(6), 647-660.

Sainati, T., Locatelli, G., Brookes, N., 2017. Special Purpose Entities in Megaprojects: empty boxes or real companies? An ontological analysis. Project Management Journal, 48 (2).

Sparks, B. A., Perkins, H. E., \& Buckley, R., 2013. Online travel reviews as persuasive communication: The effects of content type, source, and certification logos on consumer behavior. Tourism Management, 39, 1-9.

Stern, P. C., Dietz, T., Abel, T. D., Guagnano, G. A., \& Kalof, L., 1999. A value-belief-norm theory of support for social movements: The case of environmentalism. Human Ecology Review, 6(2), 81-97. Testa, F., Boiral, O., \& Iraldo, F., 2015. Internalization of Environmental Practices and Institutional Complexity: Can Stakeholders Pressures Encourage Greenwashing? Journal of Business Ethics, doi:10.1007/s10551-015-2960-2.

Turker, D., 2009a. Measuring corporate social responsibility: A scale development study. Journal of Business Ethics, 85(4), 411-427.

Turker, D., 2009b. How corporate social responsibility influences organizational commitment. Journal 
of Business Ethics, 89(2), 189-204.

732 Turner, R., \& Zolin, R., 2012. Forecasting success on large projects: developing reliable scales to

733 predict multiple perspectives by multiple stakeholders over multiple time frames. Project Management 734 Journal, 43(5), 87-99.

735 Van Marrewijk, A., Clegg, S. R., Pitsis, T. S., \& Veenswijk, M., 2008. Managing public-private 736 megaprojects: Paradoxes, complexity, and project design. International Journal of Project Management, $73726(6), 591-600$.

738 Yusof, N. A., Abidin, N. Z., Zailani, S. H. M., Govindan, K., \& Iranmanesh, M., 2016. Linking the 739 environmental practice of construction firms and the environmental behaviour of practitioners in 740 construction projects. Journal of Cleaner Production, 121, 64-71.

741 Zeng, S. X., Ma, H. Y., Lin, H., Zeng, R. C., \& Tam, V. W., 2015. Social responsibility of major 742 infrastructure projects in China. International Journal of Project Management, 33(3), 537-548.

743 Zhang, X., 2013. Going green: initiatives and technologies in Shanghai World Expo. Renewable 744 and Sustainable Energy Reviews, 25, 78-88.

745 Zhang, M., Di Fan, D., \& Zhu, C. J., 2014. High-performance work systems, corporate social 746 performance and employee outcomes: Exploring the missing links. Journal of Business Ethics, $747 \quad 120(3), 423-435$. 


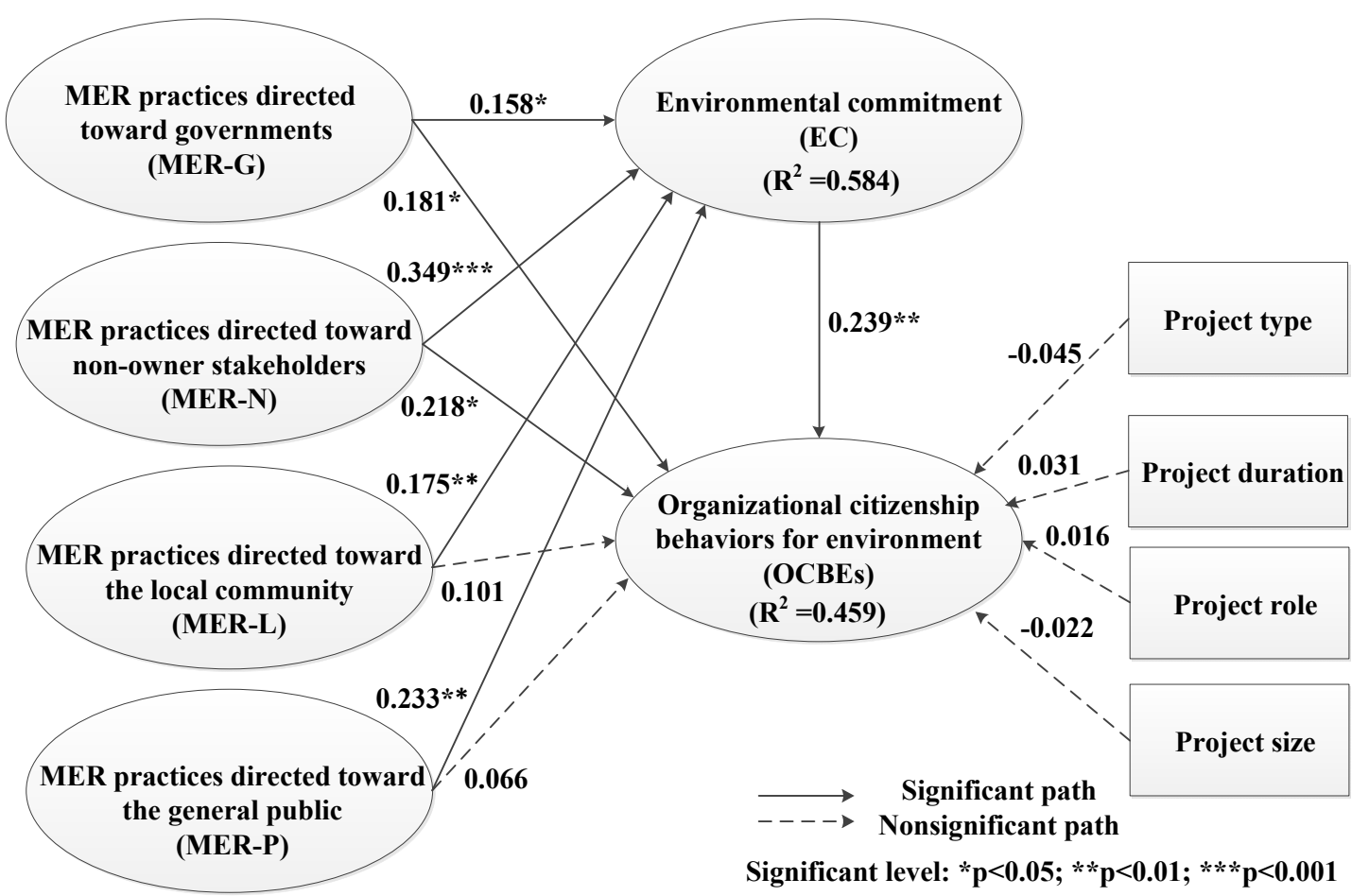

Fig. 1. Results of PLS analysis for the research model.

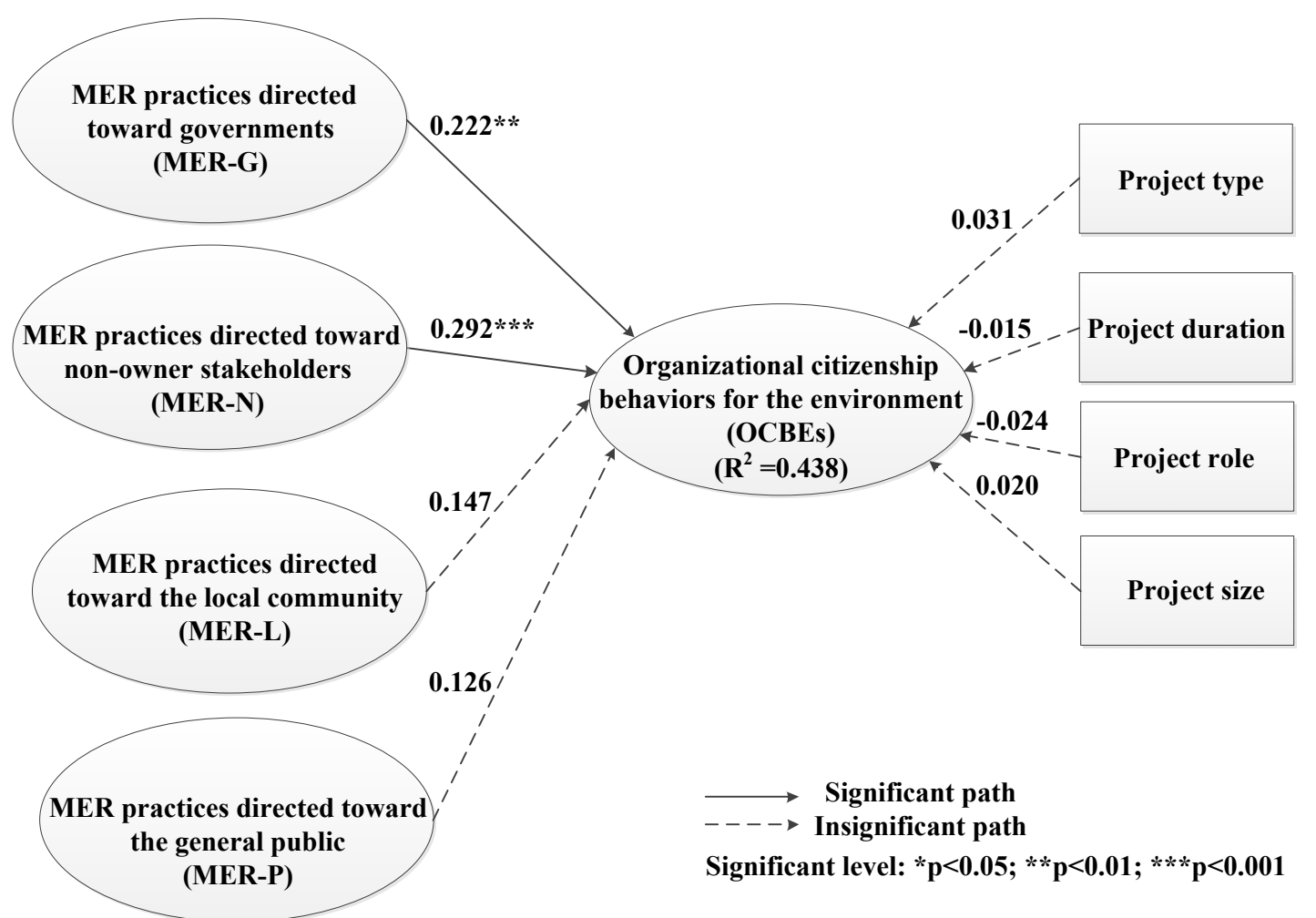

Fig. 2. Results of PLS analysis for the alternative research model. 
Table 1 Demographic information of respondents.

\begin{tabular}{|c|c|c|c|}
\hline Variable & Category & $\begin{array}{l}\text { Number of } \\
\text { respondents }\end{array}$ & Percentage \\
\hline \multirow{3}{*}{ Project role } & Owner/Government & 72 & 41.86 \\
\hline & Contractor & 61 & 35.47 \\
\hline & Consultant & 39 & 22.67 \\
\hline \multirow{6}{*}{ Project type } & Large-scale exhibition facility/ industry zone & 54 & 31.40 \\
\hline & Urban metro system & 35 & 20.35 \\
\hline & Integrated transport hubs & 31 & 18.02 \\
\hline & Energy source bases & 23 & 13.37 \\
\hline & High speed railways & 16 & 9.30 \\
\hline & Long-span bridge & 13 & 7.56 \\
\hline \multirow{5}{*}{ Location $^{\mathrm{a}}$} & East China & 76 & 44.19 \\
\hline & South China & 32 & 18.60 \\
\hline & North China & 29 & 16.86 \\
\hline & West China & 21 & 12.21 \\
\hline & Central China & 14 & 8.14 \\
\hline \multirow{4}{*}{ Position } & Project manager & 58 & 33.72 \\
\hline & Department manager & 29 & 16.86 \\
\hline & Professional executive & 41 & 23.84 \\
\hline & Project Engineer & 44 & 25.58 \\
\hline \multirow{5}{*}{$\begin{array}{l}\text { Years of } \\
\text { experience }\end{array}$} & $\leqslant 5$ year & 45 & 26.16 \\
\hline & 6-10 year & 51 & 29.65 \\
\hline & 11-15year & 42 & 24.42 \\
\hline & $16-20$ year & 19 & 11.05 \\
\hline & $>20$ year & 15 & 8.72 \\
\hline
\end{tabular}

Location $^{\mathrm{a}}$ refers to the project site where the respondent was employed at the time of the survey. 
Table 2 Component list of MER practices.

\begin{tabular}{ccccc}
\hline & \multicolumn{5}{l}{ Factor loadings } & & \\
\cline { 2 - 5 } Measurement items & Factor 1 & Factor 2 & Factor 3 & Factor 4 \\
\hline MER-N4 & $\mathbf{. 9 1 5}$ & .089 & .136 & .083 \\
MER-N5 & $\mathbf{. 9 0 2}$ & .088 & .146 & .059 \\
MER-N1 & $\mathbf{. 8 1 3}$ & .128 & .189 & .265 \\
MER-N2 & $\mathbf{. 7 0 7}$ & .345 & .181 & .274 \\
MER-N3 & $\mathbf{. 7 0 3}$ & .470 & .184 & .151 \\
MER-N6 & $\mathbf{. 5 8 4}$ & .408 & .305 & .333 \\
MER-P4 & .236 & $\mathbf{. 8 1 5}$ & .245 & -.004 \\
MER-P5 & .186 &. $\mathbf{7 9 5}$ & .336 & -.006 \\
MER-P6 & .221 & $\mathbf{. 7 8 5}$ & .188 & .107 \\
MER-P2 & .159 & $\mathbf{. 7 5 5}$ & .061 & .393 \\
MER-P1 & .064 & $\mathbf{. 6 6 8}$ & -.048 & .525 \\
MER-P3 & .150 & $\mathbf{. 5 5 9}$ & .371 & .456 \\
MER-L1 & .154 & .325 & .773 & -.066 \\
MER-L2 & .237 & .242 &. $\mathbf{7 2 1}$ & .249 \\
MER-L3 & .092 & -.248 & $\mathbf{. 6 9 7}$ & .412 \\
MER-L4 & .416 & .284 & $\mathbf{. 5 7 9}$ & .074 \\
MER-G2 & .358 & .164 & .195 & $\mathbf{. 7 2 3}$ \\
MER-G1 & .302 & .198 & .412 & $\mathbf{. 5 5 0}$ \\
Variance explained (\%) & 23.99 & 22.73 & 15.18 & 11.15 \\
Variance cumulatively explained (\%) & 23.99 & 46.72 & 61.90 & 73.05 \\
\hline
\end{tabular}

Bold values represent the factor loadings of each measurement item on its intended construct.

Table 3 Measurement validity and construct correlations.

\begin{tabular}{ccccccccc}
\hline \multirow{2}{*}{ Construct } & \multirow{2}{*}{ CR } & \multirow{2}{*}{ AVE } & \multicolumn{2}{c}{ Correlation matrix } & & & & \\
\cline { 5 - 9 } & & & MER-P & MER-L & MER-N & MER-G & EC & OCBEs \\
\hline MER-P & 0.92 & 0.66 & $\mathbf{0 . 8 1}$ & & & & & \\
& 0.86 & 0.61 & 0.58 & $\mathbf{0 . 7 8}$ & & & & \\
MER-L & & & 0.58 & 0.60 & $\mathbf{0 . 8 6}$ & & & \\
MER-N & 0.94 & 0.74 & 0.58 & & & \\
MER-G & 0.89 & 0.81 & 0.54 & 0.58 & 0.59 & $\mathbf{0 . 9 0}$ & & \\
EC & 0.93 & 0.67 & 0.62 & 0.61 & 0.68 & 0.59 & $\mathbf{0 . 8 2}$ & \\
OCBEs & 0.93 & 0.66 & 0.50 & 0.52 & 0.59 & 0.55 & 0.59 & $\mathbf{0 . 8 1}$ \\
\hline
\end{tabular}

$\mathrm{CR}=$ composite reliability; $\mathrm{AVE}=$ average variance extracted. Bold values on the diagonal represent the square root of AVE. 
Table 4 Cross loadings for measurement items.

\begin{tabular}{|c|c|c|c|c|c|c|}
\hline \multirow{2}{*}{ Code } & \multicolumn{6}{|c|}{ Item loadings } \\
\hline & MER-P & MER-L & MER-N & MER-G & $\mathrm{EC}$ & OCBEs \\
\hline MER-P1 & 0.76 & 0.32 & 0.38 & 0.42 & 0.46 & 0.36 \\
\hline MER-P2 & 0.85 & 0.42 & 0.48 & 0.46 & 0.51 & 0.33 \\
\hline MER-P3 & 0.80 & 0.61 & 0.51 & 0.50 & 0.63 & 0.47 \\
\hline MER-P4 & 0.83 & 0.50 & 0.50 & 0.39 & 0.41 & 0.35 \\
\hline MER-P5 & 0.83 & 0.52 & 0.48 & 0.41 & 0.48 & 0.42 \\
\hline MER-P6 & 0.83 & 0.46 & 0.49 & 0.42 & 0.52 & 0.48 \\
\hline MER-L1 & 0.47 & 0.77 & 0.40 & 0.38 & 0.38 & 0.33 \\
\hline MER-L2 & 0.51 & 0.86 & 0.51 & 0.50 & 0.55 & 0.45 \\
\hline MER-L3 & 0.32 & 0.71 & 0.35 & 0.42 & 0.42 & 0.33 \\
\hline MER-L4 & 0.50 & 0.79 & 0.57 & 0.49 & 0.53 & 0.50 \\
\hline MER-N1 & 0.42 & 0.51 & 0.87 & 0.52 & 0.57 & 0.52 \\
\hline MER-N2 & 0.57 & 0.51 & 0.86 & 0.57 & 0.62 & 0.51 \\
\hline MER-N3 & 0.64 & 0.53 & 0.87 & 0.51 & 0.61 & 0.55 \\
\hline MER-N4 & 0.34 & 0.45 & 0.87 & 0.46 & 0.54 & 0.44 \\
\hline MER-N5 & 0.34 & 0.44 & 0.86 & 0.42 & 0.50 & 0.47 \\
\hline MER-N6 & 0.65 & 0.61 & 0.83 & 0.56 & 0.66 & 0.50 \\
\hline MER-G1 & 0.49 & 0.57 & 0.52 & 0.90 & 0.54 & 0.51 \\
\hline MER-G2 & 0.47 & 0.46 & 0.55 & 0.89 & 0.52 & 0.48 \\
\hline $\mathrm{EC} 1$ & 0.52 & 0.55 & 0.63 & 0.53 & 0.84 & 0.54 \\
\hline $\mathrm{EC} 2$ & 0.42 & 0.45 & 0.50 & 0.40 & 0.82 & 0.48 \\
\hline EC3 & 0.40 & 0.46 & 0.50 & 0.40 & 0.73 & 0.34 \\
\hline EC4 & 0.60 & 0.58 & 0.62 & 0.56 & 0.81 & 0.53 \\
\hline EC5 & 0.50 & 0.50 & 0.54 & 0.45 & 0.83 & 0.45 \\
\hline EC6 & 0.65 & 0.47 & 0.58 & 0.55 & 0.85 & 0.53 \\
\hline EC7 & 0.41 & 0.45 & 0.47 & 0.45 & 0.84 & 0.48 \\
\hline
\end{tabular}




\begin{tabular}{lllllll} 
OCBEs1 & 0.35 & 0.44 & 0.45 & 0.40 & 0.42 & $\mathbf{0 . 7 7}$ \\
OCBEs2 & 0.44 & 0.45 & 0.51 & 0.49 & 0.53 & $\mathbf{0 . 8 7}$ \\
OCBEs3 & 0.38 & 0.36 & 0.44 & 0.37 & 0.42 & $\mathbf{0 . 7 6}$ \\
OCBEs4 & 0.42 & 0.43 & 0.43 & 0.42 & 0.45 & $\mathbf{0 . 7 9}$ \\
OCBEs5 & 0.45 & 0.42 & 0.45 & 0.47 & 0.49 & $\mathbf{0 . 8 0}$ \\
OCBEs6 & 0.41 & 0.46 & 0.56 & 0.47 & 0.56 & $\mathbf{0 . 8 6}$ \\
OCBEs7 & 0.40 & 0.42 & 0.49 & 0.50 & 0.51 & $\mathbf{0 . 8 5}$ \\
\hline
\end{tabular}

Bold values represent standardized factor loadings of the items on their respective constructs; and T-values are for these loadings.

Table 5 Results of descriptive and comparative analysis.

\begin{tabular}{cccccccccccc}
\hline & \multicolumn{2}{c}{ Full sample } & \multicolumn{2}{c}{ Project owners } & \multicolumn{2}{c}{ Contractors } & \multicolumn{2}{c}{ Consultants } & \multicolumn{3}{c}{ ANOVA } \\
\cline { 2 - 4 } Con & Mean & SD & Mean & SD & Mean & SD & Mean & SD & F-test & p-value \\
\hline MER-P & 3.35 & 0.62 & 3.31 & 0.65 & 3.40 & 0.587 & 3.33 & 0.621 & 0.296 & 0.744 \\
MER-L & 3.63 & 0.50 & 3.60 & 0.51 & 3.70 & 0.48 & 3.60 & 0.51 & 0.751 & 0.474 \\
MER-N & 3.75 & 0.68 & 3.74 & 0.67 & 3.86 & 0.69 & 3.58 & 0.65 & 2.101 & 0.125 \\
MER-G & 4.17 & 0.55 & 4.13 & 0.60 & 4.21 & 0.51 & 4.17 & 0.53 & 0.415 & 0.661 \\
EC & 3.84 & 0.63 & 3.82 & 0.66 & 3.88 & 0.60 & 3.79 & 0.65 & 0.277 & 0.758 \\
OCBEs & 4.03 & 0.60 & 3.98 & 0.63 & 4.08 & 0.56 & 4.08 & 0.59 & 0.586 & 0.558 \\
\hline
\end{tabular}

Mean $=$ arithmetic means, $\mathrm{SD}=$ standard deviation. 